\author{
A. Gounssa, K. Hormat, A. El Aboudi, F. Ezzahra, F. El Alaoui Faris \& \\ M. Arahou
}

\title{
Karyological investigation of seven Moroccan Asteraceae
}

\begin{abstract}
Gounssa, A., Hormat, K., El Aboudi, A., Ezzahra, F., El Alaoui Faris, F. \& Arahou, M.: Karyological investigation of seven Moroccan Asteraceae. [In Kamari, G., Blanché, C. \& Siljak-Yakovlev, S. (eds), Mediterranean plant karyological data - 28]. - Fl. Medit. 28: 440-445. doi: 10.7320/FlMedit28.440
\end{abstract}

The chromosome number of seven wild Moroccan species belonging to the Asteraceae family has been investigated for the first time in the region of Rabat-SaléKinétra (Morocco), using the root-tip squash. All these species show a diploid chromosome number which ranged from $2 n=18$ to $2 n=34$. Thus, we obtained for the following species: Centaurea calcitrapa $2 n=20$, Cichorium intybus $2 n=18$, Glebionis segetum $2 n=18$, Pallenis spinosa subsp. maroccana $2 n=10$, Lactuca serriola $2 n=18$, Phagnalon rupestre $2 n=18$, Silybum marianum $2 n=34$. These findings are discussed and compared with other results from elsewhere.

Keywords: Compositae, cytotaxonomy, chromosome number, Moroccan flora.

The Asteraceae family, with around 24,000-30,000 species and 1600-1700 genera, is well represented within angiosperms and is distributed around the world except for Antarctica (Friis \& Balslev 2005; Funk \& al. 2009). Many members of this family are used as aromatic and medicinal plants. Antifungal, antimicrobial, antibacterial and insecticide activities were also found in several species (Kordali \& al. 2005; Romagnoli \& al. 2005; Funk \& al. 2009). In Moroccan vascular flora, the Asteraceae family ranks first in terms of specific wealth, with 550 species and 126 subspecies belonging toaround 128 genera. Centaurea being the richest genus with 51 species. Moreover, according to the rate of endemics, this family is ranked third with $24 \%$ right after Lamiaceae and Plumbaginaceae with respectively $40 \%$ and $28 \%$ (Fennane \& Ibn Tattou 2012). In terms of aromatic and medicinal plants, Asteraceae with 36 species rank first, followed by Lamiaceae, Apiaceae and Fabaceae with respectively 30, 28 and 20 species (Fennane \& Rejdali 2016).

Concerning geographical distribution, the most important part of Moroccan vascular flora is found in semi-arid and sub-humid regions (Sauvage 1960; Fennane \& Ibn Tattou 1999; Hammada \& al. 2004), which is part our study area, Rabat-Salé-Kinétra, according to Emberger's bioclimatic subdivisions (Sauvage 1963).

Karyological studies on Moroccan flora are quite limited (El Alaoui-Faris \& al. 2011), especially in Asteraceae. Thus we can quote as preliminary studies on this family: Humphries \& al. 1978; Humphries 1979, 1981; Talavera \& al. 1984; Molero \& Montserrat 
Martí 1986; Favarger \& al. 1980; Galland 1990; Valdés \& Parra 1997; Valdés \& al. 1998; Vogt \& Oberprieler 1993, 2008, 2012; Oberprieler \& Vogt 1993; Oberprieler 1994; Hellwig \& al. 1994; Kilian \& al. 1995 and El Alaoui-Faris \& al. 2010).

The aim of this study is to provide the chromosome number of some spontaneous taxa that belong to Asteraceae family in the region of Rabat-Salé-Kénitra, and to compare it with the chromosome numbers found in other populations and countries.

1955. Centaurea calcitrapa L. $-2 n=2 \mathrm{x}=20$.

Ma: Salé, national road 1, Avenue Ouali Al Had Sidi Mohamed, 34 3' 50.425" N, $6^{\circ}$ 47' 46.316" W (RAB 108852).

Centaurea is the richest genus in the Asteraceae in Morocco, with 51 species, 24 subspecies. Sixteen species and five subspecies being strictly endemic to Morocco (Fennane \& Ibn Tattou 2012; Fennane \& al. 2014). The present chromosome count regarding this species, $2 n=20$ and the basic number $\mathrm{x}=10$, seems to be the first conducted in Morocco. Our count is in accordance with former counts conducted in Italy-Palermo (Colombo \& Marcenò 1984), Portugal (Queirós \& Viera 1990), Spain in Zaragoza province (Hellwig 1994) and Egypt (Kamel 2004).

1956. Cichorium intybus L. $-2 n=2 \mathrm{x}=18$.

Ma: Rabat, Avenue Mohamed Ben Abdellah Erregragui, 33 59' $23.827 \mathrm{~N}, 6^{\circ} 51^{\prime}$ 49.409” W. Road P4029, 34 1'2.434” N, 6 44' 5.623” W (RAB 108854).

There are two species in the genus Cichorium L. in Moroccan flora, C. intybus L. and C. pumilium Jacq. (Fennane \& al. 2014). As far as we know, our count is the first chromosome report from Morocco for this species, and it corroborates previous counts obtained in the United States of America in Los Angeles Co (Tomb \& al. 1978), Wisconsin (Löve 1981b), Pakistan in Thatta (Razaq \& al. 1994) and Spain in Puente de Alba (OrtegaOlivencia $\&$ al. 2004). The basic chromosome number $\mathrm{x}=9$ of the genus is also confirmed by our result.

1957. Glebionis segetum (L.) Fourr. $-2 n=2 \mathrm{x}=18$.

Ma: Salé, national road $1,34^{\circ} 5^{\prime} 43.508^{\prime \prime} \mathrm{N}, 6^{\circ} 45^{\prime} 48.056^{\prime}$ 'W. Road P4029, $34^{\circ} 1^{\text {' }}$ $3.042 " \mathrm{~N}, 6^{\circ} 44^{\prime} 4.261$ "W (RAB 108849).

Glebionis counts in Morocco two annual species: G. coronaria (L.) Spach and G. segetum (L.) Fourr. (Fennane \& al. 2014). This species was cytologically investigated for the first time in Morocco within populations in the province of Tetouan, Fès and Chefchaouene respectively by Vogt \& Oberprieler 1993, 1994, 2008). Our count is also in agreement with 
numerous previous reports from Portugal in Castro Verde (Queiros 1973) and the Mediterranean area e.g. Italy, in Sicily (Löve 1981a), Apulia and Sardinia (Paciolla \& al. 2010), Cyprus in Paphos (Vogt \& Aparicio 1999). Our results confirmed the basic chromosome number $\mathrm{x}=9$, which is the most common is the genus Glebionis.

1958. Lactuca serriola $\mathrm{L}$. $-2 n=2 \mathrm{x}=18$.

Ma: Salé, Avenue Jbel Toubkal, 34 4’36.649” N, 6 47’ 0.635” W (RAB 108850).

Lactuca genus presents seven species and two subspecies in Morocco. Our count is in agreement with that reported for two Moroccan populations sampled in Guercif area, Taza (Vogt \& Oberprieler 2012) and with other previous reports in different countries, ItalyValley of Aosta (Gadella \& Kliphuis 1970), Portugal-Lisbon (Queiros 1973), United States of America-California (Keil \& Pinkava 1976), Spain-Sevilla (Gallego 1981), Egypt (Kamel 2004), Japan in Karuizawa (Matoba \& al. 2007), and other countries (Mejías 1993). All these counts have shown that the basic number of this species is $\mathrm{x}=9$.

1959. Pallenis spinosa subsp. maroccana (Aurich \& Podlech) Greuter $-2 n=2 \mathrm{x}=10$.

Ma: Salé, forest Ain Houla, 34 1' 59.563” N, 6 47’ 27.585” W (RAB 108851).

The genus Pallenis is represented in Moroccan flora by five species (Fennane \& al. 2014). The subject of our investigation is endemic subspecies to Morocco and Algeria. Its chromosome number $2 n=10$ was reported for the first time in material from Morocco by Oberprieler \& Vogt (1993) in populations from Beni Mellal (Middle Atlas) and Marrakech (High Atlas). They also confirmed this number later in other Moroccan populations from Meknes and Ouezzane (Vogt \& Oberprieler 2012). Our count is also in agreement with the previous results from Portugal in Coimbra (Queiros 1973), Italy in Toscana, Garfagnana, North of Gallicano (Löve 1982), Arquà Petrarc, Euganean Hills (Marcucci \& al. 2005) and Spain in Cordoba (Ubera 1979), Navarra, Taffala (Valdés Castrillón \& Parra Martín 1998). The genus Pallenis has two basic numbers $\mathrm{x}=5$ and $\mathrm{x}=6$. The endemic subspecies maroccana has the basic chromosome number $\mathrm{x}=5$ (Oberprieler \& Vogt 1993; Vogt \& Oberprieler 2012).

1960. Phagnalon rupestre (L.) DC. $-2 n=18$.

Ma: Kénitra, lake Sidi Boughaba, 34 15'10.264" N 6 40' 9.35" W. Rabat, Avenue Ibn Hazm, $34^{\circ} 0$ ' 37.915" N, 6 50'21.447” W (RAB 108855).

The genus Phagnalon is represented in Morocco by ten species and eight subspecies. Six species and seven subspecies are endemic to Morocco; one species is endemic to Morocco, Algeria and the Iberian Peninsula (Fennane \& al. 2014). 
Our count is in agreement with the former reports based on Moroccan plants emanated from the province of Taza, Tetouan, Beni-Snassen, and Ouezzane (Oberprieler \& Vogt 1993; Vogt \& Oberprieler 2008, 2012), and with other reports from Spain in the province of Alicante and in Barcelona (Gadella \& al. 1966), the Canary Islands-Lanzarote (Van Loon 1974), and Mallorca (Luque \& al. 1984). Throughout the literature and our results, $\mathrm{x}=9$ appears to be the only basic number of this species.

1961. Silybum marianum (L.) Gaertn. $-2 n=2 \mathrm{x}=34$.

Ma: Salé, road P 4029, 34 1'2.395” N, 6 44' 5.661” W (RAB 108853).

The genus Silybum in represented in Morocco by two species: S. eburneum Cross. \& Dur. and S. marianum (L.) Gaertn. (Fennane \& al. 2014). As far as we know, this is the first chromosome report of this species in Morocco and confirms other counts on populations from Spain in Valencia and Granada (Gadella \& al. 1966), Portugal in Vila Velha de Ródão (Fernandes \& Queiros 1971) and the Canary Island in Lanzarote, Valle de Rincon (Van Loon 1974). Our result supports the basic number $\mathrm{x}=17$.

\section{References}

Colombo, P. \& Marcenò, C. 1984: Étude cytotaxinomique de Centaurea macroacantha Guss., et son affinité avec Centaurea calcitrapa L. - Webbia 38(1): 665-669.

El Alaoui-Faris, F., Tahiri, H., Ibn Tattou, M. \& Molina, J. 2010: Nombre chromosomique d'angiospermes marocaines. - Lagascalia 30(1): 19-28.

—, - Molina, J. \& El Aissami, A. 2011: Nombre chromosomique de quelques plantes a fleurs du Maroc. - Lagascalia 31: 69-76.

Favarger, C., Galland, N. \& Kupfer, P. 1980: Recherches cytotaxonomiques sur la flore orophile du Maroc. - Nat. Monspel.: Sér Bot 29: 1-64.

Fennane, M. \& Ibn Tattou, M. 1999: Observations sur la flore vasculaire endémique, rare ou menacée du Maroc. - Fl. Medit. 9: 113-124.

— \& - 2012: Statistiques et commentaires sur l'inventaire actuel de la flore vasculaire du Maroc. - Bull.Inst. Sci. 34(1): 1-9.

—, — \& El Oualidi, J. (eds) 2014: Flore Pratique du Maroc - Manuel de détermination des plantes vasculaires (Volume 3) Dicotyledone (p.p), Monocotyledones. - Institut Scientifique, Rabat.

— \& Rejdali, M. 2016: Aromatic and medicinal plants of Morocco : Richness, diversity and threats. - Bull. Inst. Sci. 38(1): 1-16.

Fernandes, A. \& Queiros M. 1971: Contribution à la connaissance cytotaxinomique des Spermatophyta du Portugal. II. Compositae. - Bol. Soc. Brot. 45: 5-121.

Friis, I. \& Balslev, H. (eds) 2005: Plant diversity and complexity patterns: local, regional and global dimensions: proceedings of an international symposium held at the Royal Danish Academy of Sciences and Letters in Copenhagen, Denmark, 25-28 May, 2003. - Kgl. Danske Videnskabernes Selskab, Copenhagen.

Funk, V. A., Stuessy, T. \& Bayer, R. 2009: Systematics, evolution, and biogeography of Compositae. - Vienna.

Gadella, T. W. J. \& Kliphuis, E. 1970: Cytotaxonomic Investigations in Some Angiosperms Collected in the Valley of Aosta and in The National Park "Gran Paradiso". - Caryologia 23(3): 363-379. 
—, — \& Mennega, E. 1966: Chromosome numbers of some flowering plants of Spain and S. France. - Acta Bot. Neerl. 15(2): 484-489.

Galland, N. 1990: Recherche sur l'origine de la flore orophile du Maroc: étude caryologique et cytogeographique. - Trav. Inst. Sci. Bot. 35: 1-168.

Gallego, M. J. 1981: Números cromosómicos para la flora Española 182-256. - Lagascalia 10(2): 225-256.

Hammada, S., Dakki, M., Ibn Tattou, M., Ouyahya, A. \& Fennane, M. 2004: Analyse de la biodiversité floristique des zones humides du Maroc. Flore rare, menacée et halophile. - Acta Bot. Gall. 29: 43-66.

Hellwig, F. 1994: Chromosomenzahlen aus der Tribus Cardueae (Compositae). - Willdenowia 24(1/2): 219-248.

-, Oberprieler, C., Vogt, R. \& Wagenitz, G. 1994: Chromosome Numbers of North African Phanerogams. III. Some Counts in Centaurea (Compositae, Cardueae). - Willdenowia 24(1/2): 249-254.

Humphries, C. J. 1979: A revision of the genus Anacyclus L. (Compositae: Anthemideae). - Bull. Nat. Hist. Mus. London Bot. 7: 83-142.

- 1981: Cytogenetic and cladistic studies in Anacyclus (Compositae: Anthemideae). - Nordic J. Bot. 1: 83-96.

Löve, Á., Murray, B., Bocquet, G. \& Vasudevan, K. 1978: Chromosome numbers of phanerogams from Morocco and Algeria. - Bot. Notiser 131(4): 391-406.

Kamel, E. A. 2004: Cytotaxonomical investigations of the Egyptian Compositae (Asteraceae). I Cardueae and Cichorieae. - Compositae Newsl. 41: 9-28.

Keil, D. J. \& Pinkava, D. J. 1976: Chromosome Counts and Taxonomic Notes for Compositae from the United States and Mexico. - Am. J. Bot. 63(10): 1393-1403.

Kilian, N., Oberprieler, C. \& Vogt, R. 1995: Chromosome Numbers of North African Phanerogams. V. Some Counts in Launaea (Compositae, Lactuceae). - Willdenowia 25(1): 273-281.

Kordali, S., Cakir, A., Mavi, A., Kilic, H. \& Yildirim, A. 2005: Screening of chemical composition and antifungal and antioxidant activities of the essential oils from three Turkish Artemisia species. - J. Agric. Food Chem. 53(5): 1408-1416.

Löve, Á. 1981a: Reports [In Löve, Á. (ed.) IOPB Chromosome Number Reports LXXII]. - Taxon 30(3): 694-708.

— 1981b: Reports [In Löve, Á. (ed.) IOPB Chromosome number reports LXX]. - Taxon 30: 68-80.

- 1982: Reports [In Löve, Á. (ed.)IOPB Chromosome Number Reports LXXVI]. - Taxon 31(3): 574-598.

Luque, T., Romero Zarco, C. M. \& Devesa Alcaraz, J. A. 1984: Números cromosómicos para la flora española: 321-330. - Lagascalia 12(2): 286-289.

Marcucci, R., Brentan, M., Carlin, S., Patrese, D. \& Tornadore, N. 2005: Reports (1415-1427). [In Kamari, G., Felber, F. \& Garbari, F. (eds), Mediterranean chromosome number reports -15]. Fl. Medit. 15: 694-702.

Matoba, H., Mizutani, T., Nagano, K., Hoshi, Y. \& Uchiyama, H. 2007: Chromosomal study of lettuce and its allied species (Lactuca spp., Asteraceae) by means of karyotype analysis and fluorescence in situ hybridization. - Hereditas 144(6): 235-243.

Mejías, J. 1993: Cytotaxonomic studies in the Iberian taxa of the genus Lactuca (Compositae). - Bot. Helv. 103(1): 113-130.

Molero, J. \& Montserrat Martí, J. 1986: Números cromosomáticos de plantas marroquíes. - Collect. Bot. (Barc.) 16(2): 351-354.

Oberprieler, C. 1994: Anthemis gharbensis (Compositae, Anthemideae), a New Species from NW Morocco. - Willdenowia 24(1/2): 83-89.

— \& Vogt R. 1993: Chromosome Numbers of North African Phanerogams. II. - Willdenowia 23(1/2): 211-238. 
Ortega-Olivencia, A., Rodríguez-Riaño, T. \& Devesa, J. 2004: Números cromosómicos para la flora española: 815-830. - Lagascalia 24: 175-182.

Paciolla C, D'Emerico S, Tommasi F, Scrugli A. 2010: Karyomorphological and biochemical studies in Glebionis coronaria (L.) Spach and Glebionis segetum (L.) Fourreau from Italy. - Pl. Biosyst. 144(3): 563-567.

Queiros, M. 1973: Contribugao para o conhecimenito citotaxonomico das Spermatophyta de Portugal, II. Compositae, Supl. 1. - Bol. Soc. Brot. 47: 299-314.

— \& Viera, M. C. 1990: Catálogo dos taxa referidos na série "contribuiçao para o conhecimento citotaxonómico das Spermatophyta de Portugal I(...)”. 2.Compositae. - Lagascalia 16(1): 15-24.

Razaq, Z. A., Vahidy, A. A. \& Ali, S. 1994: Chromosome numbers in Compositae from Pakistan. Ann. Miss. Bot. Gard. 81(4): 800-808.

Romagnoli, C., Bruni, R., Andreotti, E., Rai, M., Vicentini, C. \& Mares, D. 2005: Chemical characterization and antifungal activity of essential oil of capitula from wild Indian Tagetes patula L. - Protoplasma 225(1): 57-65.

Sauvage, C. 1960: Types biologiques et répartition par étages bioclimatiques des espèces et sous espèces de la flore du Maroc. - Doc Inédit Institut Scientiques, Rabat.

- 1963: Étages bioclimatiques: par Ch. Sauvage. - Comité National de Géographie du Maroc.

Talavera, S., Fernández-Galiano, E. \& Alcaraz, J.D. 1984: Notas cariosistemáticas sobre plantas norteafricanas: I. Compositae. - Candollea 39: 271-280.

Tomb, A. S., Chambers, K. L., Kyhos, D. W., Powell, A. M. \& Raven, P. H. 1978: Chromosome numbers in the Compositae. XIV. Lactuceae. - Am. J. Bot. 65(7): 717-721.

Ubera, J. 1979: Números cromosomáticos para la flora española: 104-109. - Lagascalia 123: 126.

Valdés, B. \& Parra, R. 1997: Números cromosómicos de plantas de Marruecos, I. - Lagascalia 20(1): 161-166.

—, - , Parrilla, R. \& Reina, C. 1998: Números cromosómicos de plantas de Marruecos, II. Lagascalia 20(2): 223-230.

Valdés Castrillón, B. \& Parra Martín, R. 1998: Números cromosómicos para la flora española: 780809. - Lagascalia 20(2): 302-308.

Van Loon, J. C. 1974: A cytological investigation of flowering plants from the Canary Islands. - Acta Bot. Neerl. 23(2): 113-124.

Vogt, R. \& Aparicio, A. 1999: Chromosome numbers of plants collected during Iter Mediterraneum 4 in Cyprus. - Bocconea 11: 117-169.

— \& Oberprieler, C. 1993: Chromosome numbers of North African phanerogams. I. - Fl. Medit. 3: 187-210.

— \& - 1994: Chromosome numbers of North African phanerogams. IV. - Candollea 49: 549-570.

— \& - 2008: Chromosome numbers of North African phanerogams. VIII. More counts in Compositae. - Willdenowia 38(2): 497-519.

— \& - 2012: Chromosome numbers of North African phanerogams. X. Plants collected during Iter Mediterraneum V of OPTIMA in Morocco. - Ann. Naturhist. Mus. Wien, Ser. B, 113: 193-221.

Addresses of the authors:

Gounssa, Abdelkarim, Hormat, Kamal, El Aboudi, Ahmed, El Alaoui Faris, Fatima

Ezzahra \& Arahou \& Moustapha,

Laboratory of Botany and Valorization of plant and fungal resources (BOVAREF), Department of Biology, Faculty of Science, Mohammed V University in Rabat. 4 Avenue Ibn Battouta, B.P. 1014 RP, Rabat, Morocco.

E-mails: abdelkarimgounssa@gmail.com; khormat@fsr.ac.ma; elaboudi@gmail. com; fzfaris@gmail.com; arahou_moustapha@hotmail.com 